UDC 662.74:552

A.S. Maloletnev ${ }^{1 *}$, Zh.K. Kairbekov ${ }^{2}$, V.S. Yemelyanova ${ }^{2}$, Zh.K. Myltykbaeva ${ }^{2}$, B.B. Baizhomartov ${ }^{2}$ ${ }^{1}$ Federal State Unitary Enterprise «Institute of combustible minerals - Research Technology Center on complex processing of combustible minerals»

${ }^{2}$ BSE Scientific Research Institute of New Chemical Technologies and Materials of the RSE Kazakh National University named after al-Farabi, Kazakhstan, Almaty

"E-mail: 'Anatoly-Maloletnev@rambler.ru; ${ }^{2}$ niinhtm@mail.ru

\title{
The deep processing of oil residues conjunction with shales
}

\begin{abstract}
The results of studies on the development of a new process of thermal cracking of tar oil as a slurry with crushed oil shale to obtain components of motor fuels. The results suggest doubtless advantages of the process before the industrial of thermo cracking, since the single-stage processing of raw materials in relatively in the mild conditions $\left(5 \mathrm{MPa}, 425^{\circ} \mathrm{C}\right.$, volumetric feed rate $\left.1.0 \mathrm{~h}-1\right)$ is achieved deep destruction of tar oil (the yield petrol fraction with a bp amounts to up to $180^{\circ} \mathrm{C}-\sim 12$ mass $\%$ of middle distillates with a bp $180-360^{\circ} \mathrm{C}-43-44$ mass $\%$, of raw material for catalytic cracking of a bp $360-520^{\circ} \mathrm{C}-\sim 15-16 \%$, based on the initial tar oil). Formed like coke products and raw materials contained in $\mathrm{V}$ and $\mathrm{Ni}$ is postponed on the mineral part of slate and removed from the reaction zone with the liquid products of the process.
\end{abstract}

Keywords: shale, tar, thermal cracking, destruction, liquid products.

\section{Introduction}

In the impossibility of increasing oil production and continued growth in demand for conventional power processing of heavy residues and high-viscosity oil, natural bitumen, coal and oil shale is becoming a strategic direction in the development of oil processing industry of Kazakhstan, Russia and the CIS countries.

New trends in Russian development of the technology is the development of oil refining catalytic cracking and catalysts of process viscosity breaking, delayed coking and hydroconversion tar. Of this set technologies promising can be recognized a process of hydroconversion of tar, which has, according to the foreign analogues, is costly and technically difficult [1].

The process of catalytic cracking is constantly improving, and the expense of new technological solutions and catalysts can reach the data described in the article: the yield of gasoline with a boiling point $205^{\circ} \mathrm{C}-51$ mass $\%$ the total yield $\mathrm{C}_{3}-\mathrm{C}_{4}$ of gases - 16 mass \%; the octane number MI - 94.2; sulfur content in petrol -0.005 mass $\%$. Indicators of the quality of new gasoline catalytic cracking catalysts (in particular the "Lyuks-2") outperforming the best foreign catalysts «Brilliant Grace» and «LS-60P» of the firm «Engelhard». However, the question remains open of energy saving new technologies, as this will determine the feasibility of new projects number [2].

Without doubt residue hydroconversion process deserves serious attention, because it allows different oils from tars get $81-86 \%$ of synthetic oil. However, the above results in the literature do not provide any information about the technical possibility of implementing and the most importantly, the material and energy consumption.

Institute GrozNRI through the process of hydroconversion of heavy oil feedstock in the lungs and middle distillates at 6-10 MPa using nanosize catalyst. In the radically of new catalytic system provided better access to the active centers of reagents. Composition is not disclosed but, according to the literature, it is - Mo catalyst developed at the Institute of Fossil Energy to process coal liquefaction and hydroprocessing of petroleum residues. A distinctive feature of this catalyst - emulsion condition with a particle size $118.6-460.3 \mathrm{~nm}$ which is reached in the 
preparation of when entering predecessors in the feedstock.

During the processing of raw materials in pilot plants is achieved yield of synthetic oil from $63.4 \%$ (raw-bitumen) to $81-86 \%$ (raw materials, oil or tar). A synthetic oil density $857-890 \mathrm{~kg} / \mathrm{m}^{3}$ does not contain metals, but contains 1.2-2 mass \% Sulfur. By the proposed flow sheet such oil is sent for further processing known techniques to produce commercial products [3].

\section{Discussion}

We jointly with FSUE «Institute of combustible minerals - Technology Center on complex processing of combustible minerals» developed a method of the joint processing of catalytic thermal Kenderlyk tar and oil shale.

The article contains results studies on the development of the process of thermal cracking of tar mixed with crushed combustible slate for components of motor fuels and raw materials for catalytic cracking. To study used ordinary Kenderlyk shale JSC «Quartz» with the following characteristics (mass \%) - $\mathrm{W}^{\mathrm{a}}-0.8 ; \mathrm{A}^{\mathrm{d}}-64.5 ; \mathrm{C}^{\mathrm{daf}}-74-77$; $\mathrm{H}^{\text {daf }}-7.3-9.9 ; \mathrm{S}^{\mathrm{d}}-0.6-1.3$; conventional organic weight shale, which was determined according to the $\left[\mathrm{OM}=100-\mathrm{A}^{\mathrm{d}}-\left(\mathrm{CO}_{2}\right)_{\mathrm{M}}\right]$ is equal to 33.2 mass $\%$.

As part of the mineral Kenderlyk shale prevail compounds of calcium, silicon and aluminum (Table 1).

Table 1 - Characteristics of the mineral oil shale deposits of Kenderlyk

\begin{tabular}{|c|c|c|c|c|c|c|c|}
\hline \multicolumn{8}{|c|}{ Content of the components in the ash, mass \% } \\
\hline $\mathrm{SiO}_{2}$ & $\mathrm{AI}_{2} \mathrm{O}_{3}$ & $\mathrm{Fe}_{2} \mathrm{O}_{3}$ & $\mathrm{CaO}$ & $\mathrm{MgO}$ & $\mathrm{SO}_{3}$ & $\mathrm{Na}_{2} \mathrm{O}$ & $\mathrm{K}_{2} \mathrm{O}$ \\
\hline 58.2 & 17.2 & 7.3 & 2.3 & 1.0 & 3.4 & - & 10.6 \\
\hline
\end{tabular}

\section{Experimental part}

As a raw material used of tar mixtures with oils of West Siberia bp. $>520^{\circ} \mathrm{C}$ with the following characteristics: the density at $20^{\circ} \mathrm{C}-0.948 \mathrm{~g} / \mathrm{cm}^{3}$, viscosity $9.7 \mathrm{C}$; the content, mass \%: $\mathrm{C}-85.60, \mathrm{H}$ $-10.72 ; \mathrm{S}-2.06 ; \mathrm{N}-0.30$; the asphaltenes -13.6 ; $\mathrm{V}$ and $\mathrm{Ni}-180$ and $90 \mathrm{~g} / \mathrm{t}$. The thermal cracking performed in RINCT\&M shaken vigorously in a reactor volume of $0.2 \mathrm{~L}$ at $400-440^{\circ} \mathrm{C}$ and an operating pressure of nitrogen $5-8 \mathrm{MPa}$ and in a flow bench setup FSUE IFE reactor with a volume of 3L at $425-435^{\circ} \mathrm{C}, 5 \mathrm{MPa}$, volumetric feed rate $1-2 \mathrm{~h}^{-1}$ and a flow rate of the mixing of reagent (nitrogen) 400500 liters per $1 \mathrm{~kg}$ of the reaction mixture.

In the preparation of pasta oil shale shredded in a ball mill to a particle size less than 200 microns slate mixed with tar in various ratios. The resulting paste was dispersed in a single plate dispersant of Pushkin-Hotuntseva with a gap between the plates of $1.0 \mathrm{~mm}$ at a speed of rotation of the movable plate $1420 \mathrm{revs} / \mathrm{min}$.

Table 2 presents the results of experimental studies on the optimization of the shale: Oil product in oil shale paste.

Data in the Table 2 that the optimal number of shale added to the tar is $15.0 \%$. When using Kenderlyk shale thermal cracking in the assumed conditions (experiment 1), we obtain a high yield of gasoline fraction with bp. to $200^{\circ} \mathrm{C}-12.5 \%$ based on the tar and diesel fraction with bp. 200$370^{\circ} \mathrm{C}-53.6 \%$. When reducing additives Kenderlyk shale to $10.0 \%$ total yield of gasoline and diesel fraction decreased from $66.1 \%$ to $55.0 \%$. Further reduction in the amount of added oil shale up to 8.0 and $5.2 \%$, resulting in a significant decrease in the yield fraction of motor fuels to $43.2 \%$ and $26.8 \%$, respectively, increases the output of heavy residue, bp. $370^{\circ} \mathrm{C}$ and coke.

Increase in the content raw pasta in petroleum shale above $15.0 \%$ is impractical because it would lead to complication of process technologies, increased erosion of apparatus mineral part of shale, the stratification of the reaction mixture on the liquid and solid phases and complexity of hardware registration node separation of the solid components from the liquid products thermal cracking.

Use in instead of thermocracking Kenderlyk raw shale sulfur shale practically does not affect the yield of the desired product of the process. The yield of gasoline and diesel fractions a total is $66.9 \%$. 
Table 2 - The results of thermal cracking of tar with different contents of shale $\left(425^{\circ} \mathrm{C}, 5.0 \mathrm{MPa}\right.$, reaction time $1.0 \mathrm{~h}$, shaken vigorously reactor)

\begin{tabular}{|l|c|c|c|c|c|}
\hline \multirow{2}{*}{ The yield of products } & \multicolumn{3}{|c|}{ № of experiments } \\
\cline { 2 - 5 } & 1 & 2 & 3 & 4 & 5 \\
\hline 1. Tar & Is taken, mass \%: & & & & \\
2. Private of Kenderlyk shale, including: & 100.0 & 100.0 & 100.0 & 100.0 & 100.0 \\
& 15.0 & 10.0 & 8.0 & 5.2 & 15.0 \\
Organic weight of shale (OMS) & & & & \\
The mineral part & 5.9 & 3.9 & 3.1 & 2.2 & 7.2 \\
& 9.1 & 6.1 & 4.9 & 3.0 & 7.8 \\
& & & & & \\
1. Gaz & Obtained in the calculation & & & & \\
2. Water & of the tar mass \%: & & & \\
3. The fraction with bp. $200^{\circ} \mathrm{C}$ & 5.7 & 4.2 & 4.0 & 3.7 & 5.7 \\
4. The fraction with bp. $200-370^{\circ} \mathrm{C}$ & 2.0 & 0.8 & 0.8 & 0.9 & 1.1 \\
5. Residue with bp. above $370^{\circ} \mathrm{C}$ & 12.5 & 13.0 & 8.8 & 8.6 & 12.4 \\
& 53.6 & 42.0 & 34.4 & 18.2 & 54.5 \\
The coke content on the mineral oil shale mass \% & 28.8 & 40.1 & 49.5 & 62.9 & 30.1 \\
\hline
\end{tabular}

Table 3 shows the results on the effect of the process temperature on the yield of the desired products thermal cracking of tar mixed with shale. At a temperature of $400^{\circ} \mathrm{C}$ output of gasoline fraction bp. to $200^{\circ} \mathrm{C}$ with a relatively small and is $9.1 \%$ based on the tar, while in the process, a sufficiently large amount of the diesel fraction (53.2\%). As the temperature of the process above $425^{\circ} \mathrm{C}$ to $440^{\circ} \mathrm{C}$ increases coke production up to $4.0 \%$ and is reduced the total yield of the readily boiling and middle distillates from $66.1 \%\left(425^{\circ} \mathrm{C}\right)$ to $61.5 \%\left(440^{\circ} \mathrm{C}\right)$. Thus, the results of experimental studies showed that the optimum temperature of the process is the interval $425-430^{\circ} \mathrm{C}$ (maximum).

Table 3 - Temperature effect on the thermal cracking mixture of shale with petroleum products. Conditions: $5.0 \mathrm{MPa}$, reaction time $1.0 \mathrm{~h}$ shaken vigorously reactor

\begin{tabular}{|l|c|c|c|}
\hline \multicolumn{1}{|c|}{ The yield of products } & \multicolumn{3}{|c|}{ Temperature, ${ }^{\circ} \mathrm{C}$} \\
\cline { 2 - 4 } & 400 & 425 & 440 \\
\hline 1. Tar & 100.0 & 100.0 & 100.0 \\
2. Private of kenderlyk shale & 15.0 & 15.0 & 15.0 \\
The yield of products, mass. \% On tar oil & & & \\
& & & \\
1. Gaz & 4.5 & 5.7 & 7.5 \\
2. Water & 1.0 & 2.0 & 0.4 \\
3. The fraction with bp. $200^{\circ} \mathrm{C}$ & 9.1 & 12.5 & 14.3 \\
4. The fraction with bp. $200-370^{\circ} \mathrm{C}$ & 53.2 & 53.6 & 47.2 \\
5. Residue with bp.above $370^{\circ} \mathrm{C}$ & 36.0 & 28.8 & 32.5 \\
The coke content on the mineral oil shale mass \% & 2.1 & 3.3 & 4.0 \\
\hline
\end{tabular}

Table 4 shows the results on the effect of the duration of the process on the yield of distillate fuel fractions. Found that the reduction in response time from $60 \mathrm{~min}$ to $30 \mathrm{~min}$ leads to de- crease in the yield of gasoline fraction and an increase in the content of middle distillate products thermal cracking with bp. $200-370^{\circ} \mathrm{C}$. On the increase response time to $120 \mathrm{~min}$.Was an increase 
in coke formation(up to $4.3 \%$ ) and reduced the total yield of gasoline and diesel fractions of $3.1 \%$ compared with the implementation process for 30 minutes.

Table 4 - Results of the thermal cracking of oil shale with a mixture of petroleum product at different duration of the process. Conditions: $425^{\circ} \mathrm{C}, 5.0 \mathrm{MPa}$, shaken vigorously reactor

\begin{tabular}{|c|c|c|c|}
\hline \multirow{2}{*}{ Data } & \multicolumn{3}{|c|}{ response time, $\min$} \\
\hline & 30 & 60 & $120 *$ \\
\hline 1. Tar & 100.0 & 100.0 & 100.0 \\
\hline 2. Private of Kenderlyk shale & 15.0 & 15.0 & 15.0 \\
\hline The yield of products, mass $\%$ on tar oil & & & \\
\hline 1. Gaz & 4.5 & 5.7 & 7.5 \\
\hline 2. Water & 1.2 & 2.0 & 2.4 \\
\hline 3. The fraction with bp. $200^{\circ} \mathrm{C}$ & 10.0 & 12.5 & 16.0 \\
\hline 4. The fraction with bp. $200-370^{\circ} \mathrm{C}$ & 57.3 & 53.6 & 48.21 \\
\hline 5. Residue with bp. above $370^{\circ} \mathrm{C}$ & 30.0 & 28.8 & 27.5 \\
\hline The coke content on the mineral oil shale wt. $\%$ & 2.9 & 3.3 & 4.3 \\
\hline
\end{tabular}

The results obtained in the reactor was shaken vigorously reflected in the implementation of the process in a Metal display with running the installation FSUE IGR (Tables 5-7).

The table shows that at $425-435^{\circ} \mathrm{C}$ anda space velocity of feed $1-2 \mathrm{~h}^{-1}$ output gasoline fractions bp. to $180^{\circ} \mathrm{C}$ is $10.8-12.6 \%$. Gasoline cracking (Table 6) contains a moderate amount of aromatic hydrocarbons $(\sim 27.0 \%)$ and unsaturated compounds (iodine number is 26.4), which provides the modern requirements for gasoline on environmentally dangerous component. However, the use of the gasoline as a motor gasoline component standard EURO (GOST R 523682005) very difficult because of the content in it 2.5 vol. \% phenol and $1.2 \%$ vol. nitrogenous base. Therefore, shale gasoline should be subjected to hydro purification in a separate step of the process, and then subjected to catalytic reforming to increase the octane number. Output of diesel fractions bp. $180-360^{\circ} \mathrm{C}$ is $32.3-44.3 \%$, which is 2.2-3 times higher. Than in industrial thermal cracking fuel oil, gas oil and coker tars. Aromatic hydrocarbons in the fractions with bp. $180-360^{\circ} \mathrm{C}$ with $53.8 \%$, but due to the high sulfur content $(1.42 \%)$ and unsaturated compounds (iodine number is 33.9) middle distillates derived from shale must also expose hydro cleaning, and for diesel fuel with a cetane number of 47-51 items require partial hydrogenation of aromatic hydrocarbons.

In the developed a new process of thermal cracking of tar with slate remains unturned to $34 \%$ of the heavy residue from bp. above $520^{\circ} \mathrm{C}$. This residue is not very different in their physical and chemical properties (Table 7) from the original tar and can be returned for processing in the form of a mixture with the starting material.

It should be noted that the thermal cracking of tar with the addition of oil shale are mild flatulence (6.0-7.7 mass \%), Which provides a high yield (above 90\%) and ash-free hydrogenation components of motor fuels (above 55\%). The resulting gas is composed primarily of hydrocarbons $\mathrm{C}_{1}-\mathrm{C}_{4}$ (Table 5), which can be used on sbstvennye goals in the process. An important fact is also almost complete otsutsvtie in the process of hydrogen gas, which is produced in large quantities in industrial thermal contact cracking (TCC) and is lost when burned.

Based on the experimental data the schematic diagram (Figure 1) thermal cracking the heavy oil residues with bp. $520^{\circ} \mathrm{C}$ into motor fuel and raw materials for catalytic cracking. 
Table 5 - Material balance (mass \%) of contact thermal cracking of tar mixed with fuel of Kenderlyk shale (5 MPa nitrogen supply 400-500 1/1 raw bench flow setting)

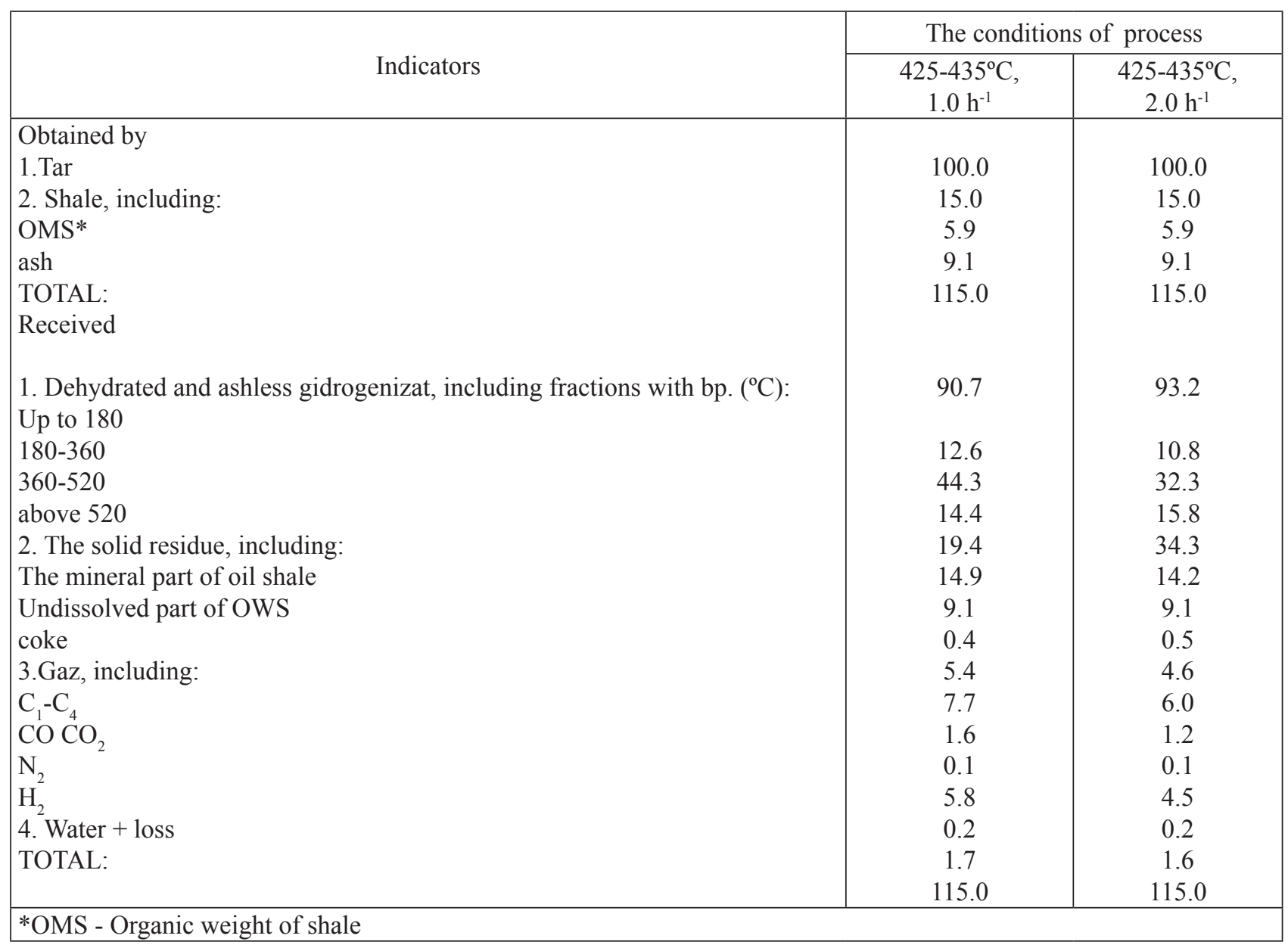

Table 6 - Characteristics of distillate of products thermal cracking of tar mixed with shale

\begin{tabular}{|c|c|c|c|}
\hline \multirow{2}{*}{ Indicators } & \multicolumn{3}{|c|}{ The fractions with bp., ${ }^{\circ} \mathrm{C}$} \\
\hline & to 180 & $180-360$ & $360-520$ \\
\hline Density at $20^{\circ} \mathrm{C}, \mathrm{g} / \mathrm{cm}^{3}$ & 0.7666 & 0.8696 & 0.9295 \\
\hline Content, $\%$ : & & & \\
\hline phenols & 2.5 & 1.5 & - \\
\hline nitrogenous bases & 1.2 & 4.2 & - \\
\hline Of hydrocarbon sucking mass $\%$ : & & & \\
\hline Paraffin + naphthenic & 72.7 & 46.2 & 22.2 \\
\hline aromatic & 27.3 & 53.8 & 61.1 \\
\hline Silicagel resin & - & - & 16.7 \\
\hline asphaltenes & - & - & 3.4 \\
\hline Iodine number, $\mathrm{g} \mathrm{I}_{2} / 100 \mathrm{~g}$ & 26.4 & 33.9 & 12.5 \\
\hline The elemental composition, wt. \%: & & & \\
\hline $\mathrm{C}$ & 85.50 & 86.20 & 86.57 \\
\hline $\mathrm{H}$ & 13.82 & 12.20 & 11.19 \\
\hline $\mathrm{S}$ & 0.60 & 1.42 & 1.97 \\
\hline $\mathrm{N}$ & 0.08 & 0.18 & 0.27 \\
\hline Content, $\%$ : & & & \\
\hline $\mathrm{V}$ & - & - & 5.0 \\
\hline $\mathrm{Ni}$ & - & - & 20.0 \\
\hline
\end{tabular}


Table 7 - Characteristics of tar residue hydrocracking mixed with shale

\begin{tabular}{|l|l|l|}
\hline \multicolumn{1}{|c|}{ The index } & Heavy residue $\mathrm{bp} .>520^{\circ} \mathrm{C}$ & \multicolumn{1}{|c|}{ Solid residue of Process } \\
\hline The density at $20^{\circ} \mathrm{C}, \mathrm{g} / \mathrm{cm}^{3}$ & 1.0361 & - \\
Asphaltene content, mass \%: & 16.3 & - \\
Elemental composition, mass \%: & & - \\
$\mathrm{C}$ & 83.80 & - \\
$\mathrm{H}$ & 9.46 & 1.0 \\
$\mathrm{~S}$ & 1.68 & - \\
$\mathrm{N}$ & 0.64 & - \\
About & 4.42 & \\
The content, $\mathrm{g} / \mathrm{t}$ & & 1017.0 \\
$\mathrm{~V}$ & 125.0 & 766.0 \\
$\mathrm{Ni}$ & 103.0 &
\end{tabular}

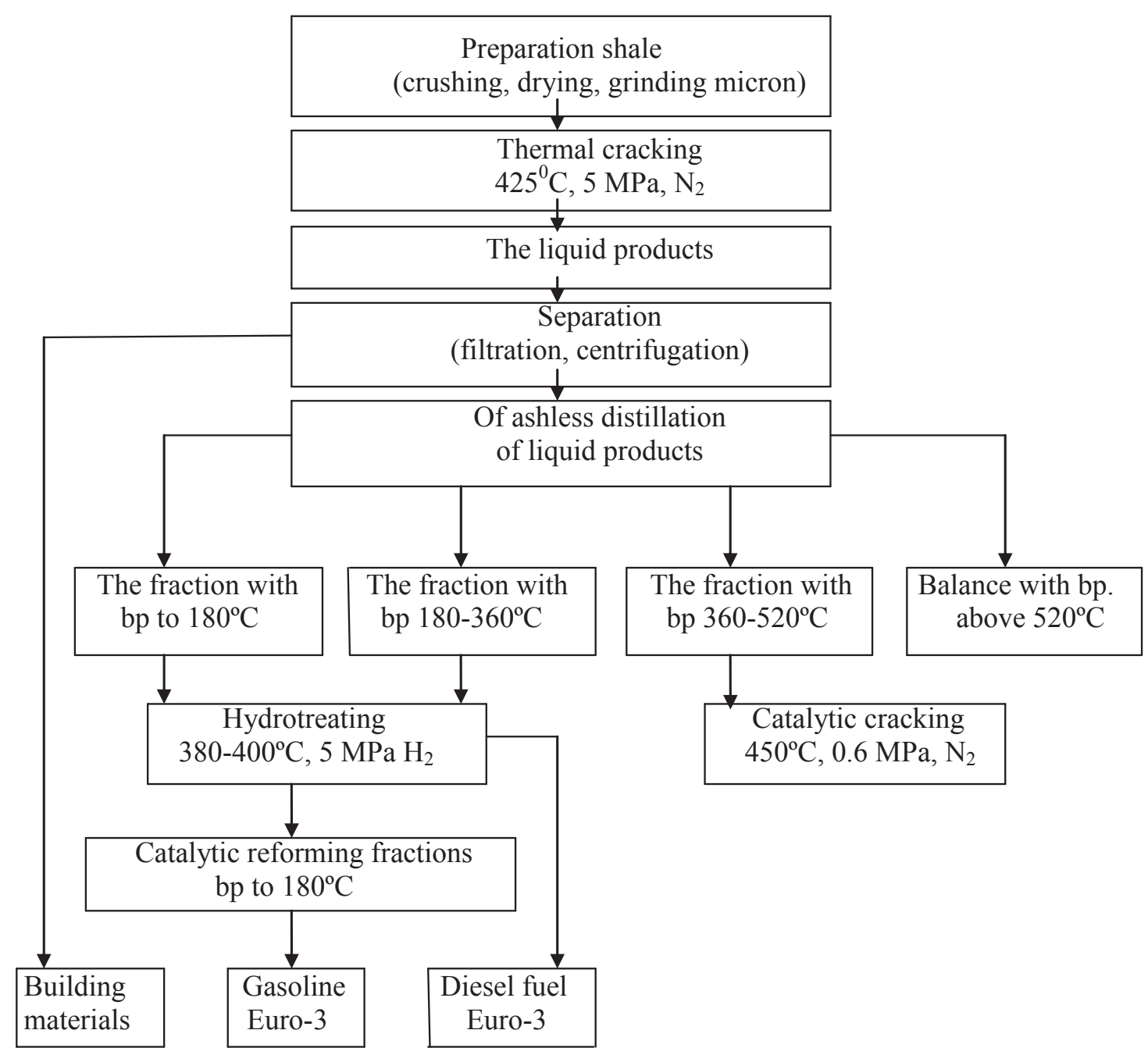

Figure 1 - Schematic diagram of the thermal cracking of tar mixed with oil shales 


\section{Conclusion}

The results of experimental investigations clearly show the undoubted advantages of the new process of thermal cracking of tar mixed with slate before the industrial thermal cracking, since the single-stage processing in relatively mild conditions $(5 \mathrm{MPa}$, $425^{\circ} \mathrm{C}$, volumetric feed rate $1.0 \mathrm{~h}^{-1}$ ) reached deep destruction tar (output gasoline diffraction with bp. to $180^{\circ} \mathrm{C}$ is $\sim 12$ mass $\%$ of middle distillates with bp. $360-520^{\circ} \mathrm{C}-\sim 15-16 \%$ based on the original tar). Formed coke shaped products and raw materials contained in $\mathrm{V}$ and $\mathrm{Ni}$ deposited on the mineral and oil shale are derived from the reaction zone with the liquid products of the process.

\section{References}

1 Susuki S. Utilization of heavy oil - Thermal cracking of vacuum residues by Eureva Process // Chem. Equip. and Eng. Review, 1978. - №2. P. 30.

2 Нефедов Б.К. Углубленная переработка нефтяных остатков как стратегическое направление развития нефтеперерабатывающей промышленности России в 2010-2020 гг. // Катализ в промышленности. - 2010. - №4. - С. 39-50.

3 Газимзянов Н.P. IX Конференция по технолоогиям нефтепереработки России и стран СНГ // Катализ в промышленности. - 2010. №1. - C. 78-80.

\section{А.С. Малолетнев, Ж.Қ. Қайырбеков, В.С. Емельянова, Ж.Қ. Мылтықбаева, Б.Б. Байжомартов Мұнай қалдықтарының сланцтармен бірге терең өңдеу}

Мотор отындарының компоненттерін алу үшін майдаланған жанғыш сланцтар мен гудронды суспензия түрінде термиялық крекинглеу жаңа процесі жасалып, зерттеу нәтижелері көрсетілген. Алынған нәтижелер көрсетілгендей, өндірістік термокрекинг пен салыстырғанда үлкен басымдылыққа ие, өйткені шикізатты бір сатылы салыстырмалы жұмсақ жағдайларда (5 МПа, $425^{\circ} \mathrm{C}$, көлемдік шикізатты беру 1.0 ч-1) өңдегенде гудронның терең деструкциясына жетеді (қТ $180^{\circ} \mathrm{C}$-қа дейін бензинді фракцияның шығуы $\sim 2$ масс.\%; кТ $180-360^{\circ} \mathrm{C}$ орташа дистилляттардың шығуы 43-44 масс.\%; қТ. 360-520 ${ }^{\circ} \mathrm{C}$ каталитикалық крекингке арналған шикізаттың шығуы 15-16\% бастапқы гудронға есептегенде).Түзілетін кокс өнімдері мен шикізаттың құрамындағы V мен Ni сланцтардың минералды бөлшектерінде жиналып, сұйық өнімдер мен бірге реакциялық аймақтан шығарылады.

Tүйін сөздер: жанғыш сланцтар, шайыр, термикалық крекинг, ыдырау, сұйық өнімдер.

\section{А.С. Малолетнев, Ж.К. Каирбеков, В.С. Емельянова, Ж.К. Мылтыкбаева, Б.Б. Байжомартов Глубокая переработка нефтяных остатков совместно со сланцами}

Приведены результаты исследований по разработке нового процесса термического крекинга гудрона в виде суспензии с измельчёнными горючими сланцами для получения компонентов моторных топлив. Полученные результаты свидетельствуют о несомненных преимуществах процесса перед промышленным термокрекингом, так как при одноступенчатой переработке сырья в относительно мягких условиях (5 МПа, $425^{\circ} \mathrm{C}$, объёмная скорость подачи сырья 1.0 ч-1) достигается глубокая деструкция гудрона (выход бензиновой фракции с т.кип. до $180^{\circ} \mathrm{C}$ составляет $\sim 12$ масс.\%; средних дистиллятов с т.кип. $180-360^{\circ} \mathrm{C} 43-44$ масс.\%; сырья для каталитического крекинга с т.кип. $360-520^{\circ} \mathrm{C} \sim 15-16 \%$ в расчёте на исходный гудрон). Образующиеся коксообразные продукты и содержащиеся в сырье V и Ni откладываются на минеральной части сланца и выводятся из реакционной зоны с жидкими продуктами процесса.

Ключевые слова: горючие сланцы, смола, термический крекинг, деструкция, жидкие продукты 